\title{
HUMOR E IRREVERÊNCIA NOS IMPRESSOS ESTUDANTIS DE ESCOLAS NORMAIS RURAIS (RS, 1945-1983)
}

\author{
Flávia Obino Corrêa Werle \\ Universidade do Vale do Rio dos Sinos, Brasil.
}

\section{$\cos 8$}

Resumo

Este estudo discute um tipo de cultura escolar que contribui para a formação dos estudantes e revela práticas pedagógicas. O foco da discussão são os impressos estudantis, os quais são analisados como espaço educativo, de expressão e organização dos alunos. Aspectos relacionados ao humor e irreverência são analisados nos impressos produzidos por estudantes de duas escolas normais rurais do Rio Grande do Sul, Brasil. Palavras-chave: formação de professores, impressos estudantis, cultura escolar.

\section{HUMOR AND IRREVERENCE IN THE STUDENT'S JOURNAL IN RURAL NORMAL SCHOOLS (RS, 1945-1983)}

\section{Abstract}

This paper discusses a type of school culture that contributes to the training of students and pedagogical practices reveals. The focus of the discussion are the student's journal which are analyzed as educational space, expression and organization of students. Aspects related to humor and irreverence are examined in printed materials produced by students from two rural normal schools of Rio Grande do Sul, Brazil.

Key-words: teacher training, student's journal, school culture.

\section{EL HUMOR Y LA IRREVERENCIA EN LOS IMPRESOS DE ESTUDIANTES DE LAS ESCUELAS NORMALES RURALES (RS, 1945-1983)}

Resumen

En este trabajo se analiza un tipo de cultura escolar que contribuye a la formación de los estudiantes y las prácticas pedagógicas. El foco de la discusión son los impresos de estudiantes que se analizan como espacio educativo, de expresión y organización de los 
estudiantes. Aspectos relacionados con el humor y la irreverencia son examinados en los materiales impresos producidos por estudiantes de dos escuelas normales rurales de Rio Grande do Sul, Brazil.

Palabras-clave: formación del profesorado, los estudiantes impreso, la cultura escolar.

\section{L'HUMOUR ET L'IRREVERENCE IMPRIMÉ EN ÉTUDIANT DE L'ÉCOLE NORMALE EN MILIEU RURAL (RS, 1945-1983)}

\section{Résume}

Le présent document traite d'un type de culture scolaire qui contribue à la formation des étudiants et des pratiques pédagogiques révèle. Le thème de la discussion sont sudent's journal qui sont analysés comme l'espace, l'expression et l'organisation pédagogique des étudiants. Les aspects liés à l'humour et l'irrévérence sont examinés dans des documents imprimés produits par les élèves de deux écoles normales rurales du Rio Grande do Sul, Brazil.

Mots-clé: formation des enseignants, étudiants imprimé, la culture scolaire. 
expressão cultura escolar tem, na historiografia da educação, sentidos
diversos. Abrange normas, práticas de transmissão (Julia, 2001), teorias,
idéias, princípios, rituais, inércias, hábitos e práticas (Viñao Frago, 2001), bem como descreve tempos, espaços, sujeitos, conhecimentos e práticas escolares (Faria Filho et al., 2004).

Neste texto cultura escolar é entendida de forma ampla, como normas e práticas, tempos, espaços, princípios de ação e aspectos curriculares. Situam-se nesta conceituação ampla de cultura escolar os impressos estudantis. Estes, como uma forma específica de cultura escolar, fazem parte de um vasto conjunto de meios de comunicação e publicação referenciados à educação. Imprensa pedagógica e imprensa educacional são algumas das designações que tais fontes podem receber.

Nóvoa (1997) cita imprensa educacional, que inclui amplo espectro de publicações as quais revelam elementos internos ao sistema de ensino - cursos, programas, currículos -, bem como descrevem o papel desempenhado pelas famílias e pelas diversas instâncias de socialização das crianças e dos jovens. Este autor reconhece a imprensa educacional como um meio de afirmação de grupos e espaço de regulação coletiva, pois possibilita a manifestação e a audição de vozes pouco consideradas em outros espaços sociais.

Bastos (1997) designa como imprensa periódica pedagógica jornais, boletins, revistas, magazines, independentemente do público a que se destinem e em que instância tenham tido origem. Tanto publicações feitas para professores ou destinadas a professores, como as elaboradas por alunos para os demais alunos, ou por professores para alunos, ou mantidas pela hierarquia do sistema educacional ou por outras instituições ligadas à educação, tais como sindicatos, associações de classe, Igreja, partidos políticos.

O caráter formativo dos impressos, aliado ao de divulgação de idéias e releitura de acontecimentos, é destacado por Desaulniers (1997). Tal como Bastos, Desaulniers reitera que os impressos não reproduzem os fatos, ao contrário, retrabalham, modulam, acontecimentos, crivam de nuances as informações e as fazem circular, disseminando-as em diversos espaços. Nóvoa (1997), entretanto, destaca que a imprensa educacional produz uma "reflexão muito próxima do acontecimento" (p. 13), ou seja, o impresso testemunha fatos do contexto da época, registra opiniões e reações produzidas no imediato dos acontecimentos.

Duas são as linhas de abordagem de periódicos: uma centrada na análise interna do próprio impresso e sua produção, o ciclo de vida - duração, periodicidade, agentes responsáveis, colaboradores, recorrências e predominâncias temáticas -, e outra que permite reconstruir o campo educacional e as disputas, os debates empreendidos e os grupos neles envolvidos (Catani; Sousa, 1999). Estas autoras, ao citar Pierre Caspard, afirmam que

um instrumento desse tipo não é metodologicamente neutro. As revistas analisadas não constituem um corpus em si que bastaria identificar e descrever. É necessário inventar esse corpus, isto é, tomar posição sobre uma acepção do campo educativo e manter em função dessa acepção as revistas pertinentes. (Ibid., p. 13) 
A imprensa estudantil é um tipo de imprensa periódica educacional, produzida em instituições escolares que atendem a essas características ao fornecer indícios da interpretação e significado que os alunos atribuíam à vida escolar, suas práticas, seus valores, seus ritos, suas crenças e seus símbolos. É uma imprensa constituída por grupos de alunos que, por curto período de tempo, estão na escola e que caracterizam, em seus escritos, ocorrências e imagens diretamente vinculadas aos atores que thes são contemporâneos, presentes na instituição, e ao específico momento histórico institucional. Ou seja, é um espaço em que são expressos processos de influência, de produção, de disseminação de opiniões e de informações acerca das relações entre estudantes, professores, direção, turmas de alunos, interações entre diferentes estabelecimentos escolares e com a comunidade externa à escola, bem como acerca da proposta formativa da escola, valores e objetivos compartilhados ou que devam ser reforçados, reafirmados.

Os impressos são práticas de representação e assumem a perspectiva dos sujeitos que as produzem e que, por outro lado, nelas se produzem. Não são, portanto, neutros, como lembrado acima. Ademais, os impressos estudantis são um espaço de manifestação de vozes silenciadas, as dos alunos, embora ocorram casos em que, sob o título de impressos estudantis, se constituam vozes oficiais e da hierarquia do sistema escolar.

Amaral e Silva, em 2005, ao discutir o tema dos impressos estudantis, reforçam a necessidade de implementar estudos sobre estes artefatos culturais:

Nos estudos que privilegiam a investigação das práticas culturais, seus sujeitos e produtos, os impressos estudantis são considerados elementos potenciais para a apreensão do espaço e do fazer escolar. Atualmente no Brasil o uso dessas fontes, em pesquisas relacionadas à história da educação, ainda, são pouco exploradas. [...] A imprensa estudantil torna-se um importante instrumento de trabalho que poderá revelar as inúmeras facetas dos processos escolares, fazendo emergir outros aspectos antes ignorados. [...] A imprensa estudantil constitui-se em artefato cultural produzido por alunos, para seus pares e comunidade escolar que evidenciam o seu modo de percepção das práticas e discursos. (Amaral; Silva, 2005, p. 1)

Afirmam as autoras que há nos impressos estudantis, jornais e revistas, uma predominância de textos produzidos por alunos, embora também registrem a participação de outras pessoas que faziam ou não parte da instituição: diretores, inspetores escolar, ex-alunos e associações de outras escolas.

Este texto focaliza certa forma de expressão - os desenhos, logotipos, caricaturas e piadas - presentes em impressos de duas escolas normais rurais. A literatura registra que esta forma de expressão era presença constante nos impressos estudantis. $O$ foco para este tipo de informação decorre do interesse em identificar espaços de insubordinação, de transformação da cultura escolar e, mais especialmente, a visão dos alunos das relações escolares.

A hipótese inspiradora da análise prende-se à possibilidade de que impressos estudantis constituam-se em espaço que abrigue a manifestação da consciência subjetiva dos alunos os quais, como anteriormente afirmado, são atores pouco visíveis no contexto 
da história das instituições escolares e da historiografia do país. Em geral, prevalece a concepção de que eles são pouco capazes de demonstrar uma posição ativa frente às relações sociais e às estruturas das instituições educativas.

Ora, se há que pesquisar espaços em que se possa perceber a ação dos indivíduos na construção dos laços sociais, os impressos estudantis podem dar a ver tal ação. Daí que este artigo procura um deslocamento do foco analítico "das estruturas para as redes, dos sistemas de posição para as situações vividas, das normas coletivas para as estratégias singulares" (Chartier, 2002, p. 82).

Nesse sentido, o esforço analítico é destacar situações vividas, redes, estratégias singulares, compostas e expressas por alunos em impressos estudantis. Um autor importante que discute as micro resistências, as redes de práticas singulares é Michel de Certeau. Ele enfatiza a necessidade de analisar como aqueles que não produzem as políticas e nem ocupam espaços de poder formal, mas estão na linha de frente como subalternos, no caso deste artigo os alunos, manipulam e se utilizam destas políticas, ainda que vivam dentro delas:

Se é verdade que por toda a parte se estende e se precisa a rede da vigilância, mais urgente ainda é descobrir como é que uma sociedade inteira não se reduz a ela: que procedimentos populares (também minúsculos e cotidianos) jogam com os mecanismos da disciplina e não se conformam com ela a não ser para alterá-los; enfim, que maneiras de fazer formam a contrapartida, do lado dos consumidores (ou dominados?), dos processos mudos que organizam a ordenação sócio-política. (Certeau, 2011, p. 40- 41)

Busca-se, portanto, discutir como os impressos estudantis se constituem em espaços de autonomia, de insubordinação, de apropriação, de recontextualização, de recepção, de micro resistências, de inércias e de manifestação de ações e modos de praticar diferenciados, os quais são metáforas da ordem estabelecida e que manifestam, a um só tempo, o exercício e a burla da lei e da norma.

A insubordinação burocrática, expressão cunhada por Licínio Lima (2001), de alguma forma acena para entender "como os indivíduos produzem o mundo social, por meio de suas alianças e seus confrontos, através de suas dependências que os ligam ou dos conflitos que os opõem" (Chartier, 1990, p. 102). Tais conceitos dão fundamentação à abordagem do objeto de estudo proposto neste artigo.

Os mecanismos que regulam a vida social estão perpassados por controles, mas também por intervenções subjetivas, ou seja, as relações sociais são atravessadas por estratégias comunitárias, grupais e individuais. Em outras palavras, dentro de um sistema de normas há distâncias, discordâncias, e a hipótese é que os alunos constroem, em alguns espaços dos impressos estudantis, formas de manifestação destas distâncias e discordâncias. Distâncias e discordâncias que poderão ser para com seus próprios colegas, seus pares, professores e a administração da escola, assim como perante a sociedade mais ampla.

O artigo analisa impressos estudantis de duas escolas, uma católica, a Escola Normal Rural La Salle de Cerro Largo, e outra evangélica, a Escola Normal Rural Presidente Getúlio Vargas de Três de Maio, ambas criadas em fases diferentes de 
desenvolvimento da formação de professores para as zonas rurais no Estado do Rio Grande do Sul.

A metodologia de trabalho consistiu em análise realizada em dois tempos. Inicialmente mapeou-se o conjunto de exemplares com vistas a identificar a designação, o ano, o número, a data, o vínculo com o grêmio literário e respectiva presidência em exercício, os títulos das matérias e a publicidade veiculada. Num segundo momento a análise contemplou o conteúdo das matérias, incluindo seu resumo e categorização conforme a temática contemplada. Estes dois momentos são preliminares e organizadores do material empírico. A análise orientada para o quadro teórico deste artigo produz-se a partir desta visão panorâmica inicial acerca dos dados disponíveis. Neste texto são analisados, especificamente, os desenhos, as charges e seção de humorismo.

\section{Visitando estudos acerca de impressos estudantis}

Vários estudos relacionam os impressos estudantis à criação e atuação de grêmios de alunos (Nery, Serra, 2012; Serra, 2009; Serra, 2011; Silva, 2009). O Estímulo foi um impresso publicado pelos normalistas da Escola Normal Secundária da Capital, São Paulo, no período de 1906 a 1927. Estes se organizavam em uma associação dos alunos, chamada de Grêmio Normalista Dois de Agosto. O Estímulo era um impresso que divulgava os conteúdos ministrados em classe, trazia transcrições de aulas, questões pedagógicas, exercícios realizados pelas turmas, temas educativos, especialmente os que envolviam a escola normal, e incluía assuntos administrativos, edifício escolar e missão docente. Contava sempre com o acompanhamento de professores e a supervisão da direção do estabelecimento de ensino.

Serra (2009, p. 5) afirma que "a composição do grêmio, as normas de seu funcionamento e o acento das questões técnico-burocráticas não favoreciam a participação dos alunos de modo a contribuir decisivamente para a definição do projeto editorial e a publicação da revista". A revista do grêmio normalista cumpria, de fato, a função de dispositivo de normatização pedagógica. A autora afirma que a política e a administração pública tinham muita influência de maneira a repercutir no cenário de política e gestão do grêmio.

Ainda segundo Serra (2011), O Estímulo abordava seguidamente temas como pátria, civismo, Deus e estava muito ligado à hierarquia educacional, o que é identificado pela autora na medida em que publicava fotos dos professores, dos diretores, das turmas, além de ilustrações com a fachada da escola e a bandeira brasileira.

Excelsior! era a revista da Escola Normal de São Carlos, São Paulo, e tal como a revista $O$ Estímulo publicava artigos acerca de tendências pedagógicas, exercícios realizados em aula, textos literários e conferências pedagógicas ocorridas na escola, instituindo-se como uma "entidade tutelada pela direção da escola" (Silva, 2009, p. 18). Publicavam na revista professores, diretores, secretários da escola, homens de influência da sociedade local e também administradores da educação. O Grêmio Normalista Vinte e Dois de Março, ao contrário do que se possa pensar, não surgiu da iniciativa dos alunos, mas do diretor da escola; ademais, "a Diretoria Geral da Instrução Pública [participava] de 
forma indireta das decisões do grêmio, por meio do financiamento dos primeiros números da revista e no comentário do próprio diretor da escola" (Ibid., 2009, p. 16).

Excelsior! era uma revista de excelente aparência, com primoroso tratamento editorial e tipográfico. Seu último número foi publicado em 1916. Com seu encerramento, teve início a publicação da Revista da Escola Normal de São Carlos, subvencionada pela Câmara Municipal da cidade (Silva, 2009). As pesquisas acerca dos impressos estudantis em São Paulo os relacionam à criação de grêmios estudantis, mas desvelam periódicos altamente controlados por professores, diretores e pela hierarquia do sistema escolar. Portanto, tais impressos se afiguram como exemplos contrários à hipótese inspiradora da análise empreendida neste artigo, a qual prende-se à possibilidade de que impressos estudantis constituam-se em espaço que abrigue a manifestação da consciência subjetiva dos alunos.

No Rio Grande do Sul encontramos pesquisas acerca de impressos estudantis (Amaral, 2002, 2003; Pineda, 2007). Para Amaral (2002) a importância dos impressos estudantis está na possibilidade de fornecerem "configurações especificas da vida e da cultura escolar, onde se pode constatar denúncias, expectativas e idealizações (principalmente de alunos) referentes à educação e ao cotidiano das escolas" (p. 123). A autora destaca o caráter não oficial desses periódicos, sua irreverência e crítica, que se expressam por "representações satíricas e caricaturizadas da sociedade, da escola, de professores e de alunos" (Ibid., p. 123).

Referindo-se ao periódico Ecos Gonzagueanos, impresso estudantil do Colégio Gonzaga, um colégio católico masculino da cidade de Pelotas, Amaral (2003) registra as diferentes designações que o impresso assumiu ao longo do tempo: Ensaio, O Pagode, $O$ Cientista, Vida, O Alvorecer, O Estudante, O Gonzagueano. Identificamos também essa variação de nomes em nossa pesquisa para os impressos da escola normal rural. O Ecos Gonzagueanos tinha censores que acompanhavam e avaliavam as matérias que seriam publicadas, o "irmão Henrique Miguel e o prof. Rafael Alves Caldellas" (Amaral, 2003, p. 170). No caso das fontes encontradas na escola normal rural, também há registros de professores que acompanhavam, supervisionavam o que era publicado e, muitas vezes, colaboravam com artigos.

Pineda (2003) analisou a revista dos alunos do Colégio Militar de Porto Alegre, publicada entre 1922 e 1938, denominada Hyloea. Esta se caracteriza como uma revista literária e como órgão oficial do grêmio estudantil, cuja comercialização alcançava outros Estados brasileiros:

Suas páginas contêm textos abordando diversos temas: esportes, o cotidiano da escola, contos, romances, sociedade, educação, política e as mulheres. O universo feminino constituiu-se como tema mais freqüente no periódico. Dos 1.373 artigos, poemas, contos e ensaios existentes na revista no período em questão, 641 referiam-se à mulher, totalizando $46,62 \%$ das matérias publicadas. É impossível, portanto, não constatar a significativa presença do tema mulher no periódico dos alunos do Colégio Militar de Porto Alegre. (Pineda, 2007, p. 10)

Os estudos referidos anteriormente deixam antever a diversidade dos impressos estudantis. Em alguns a presença dos alunos é praticamente invisível, tal o nível de tutela 
e controle de parte do corpo docente, direção e hierarquia do sistema escolar. Outros são mais próximos das vivências dos alunos, mais simples em sua apresentação e aspecto gráfico. Há alguns estudos acerca de impressos estudantis, mas não especificamente acerca de impressos produzidos em escolas normais rurais que é o foco deste artigo. Assim, preliminarmente situamos a escola normal rural no conjunto da escola brasileira, para depois configurar os estabelecimentos cujos impressos analisamos.

\section{Escola normal rural: panorama brasileiro}

No período Imperial, todo e qualquer estabelecimento que formasse professores era designado de Escola Normal, sem qualquer qualificativo ou especificação em sua cultura escolar decorrente de diversidades regionais em que o trabalho dos futuros professores fosse realizado (Werle, 2008). Nos currículos predominavam os estudos propedêuticos e a formação pedagógica era marcada fortemente pela prática com alunos e pelo exemplo de professores mais experientes (Werle, 2003) ${ }^{1}$. Este perfil de cultura escolar em escolas de formação de professores alterou-se progressivamente ao longo das primeiras décadas do século 20 pela instalação das escolas normais rurais, aproximando-o da perspectiva do ruralismo pedagógico (Prado, 1995).

Este texto ${ }^{2}$ discute uma parte da história institucional, num aspecto de sua cultura escolar, aquele decorrente e explicitado em impressos estudantis. Tem como espaço empírico a escola normal rural criada nos anos 1940 e início da década de 1950, como iniciativa vinculada ao contexto sociopolítico do Rio Grande do Sul. As primeiras escolas normais rurais estavam diretamente ligadas às iniciativas das igrejas e a necessidade de expandir o ensino público a todas as regiões do Estado, necessidade esta não associada às políticas públicas articuladas a partir do núcleo do governo e nem exclusivamente voltadas para a formação do magistério. Compreendemos que as escolas normais rurais passaram por duas fases de implantação.

Pertencem à primeira fase a Escola Normal Rural da Arquidiocese, de Porto Alegre, mantida pelos irmãos Maristas, situada onde hoje é o Colégio Champagnat, no campus da PUCRS, a Escola Normal Rural La Salle de Cerro Largo e a Escola Normal Rural Murialdo, situada em zona de colonização italiana, em Ana Rech, Caxias do Sul. A segunda fase de criação das escolas normais rurais dá-se na vigência da Lei Orgânica do Ensino Normal, a partir de 1946, quando outras mantenedoras, já não mais necessariamente vinculadas à Igreja Católica, oferecem o Curso Normal Rural. As escolas desta segunda fase apresentam características diferenciadas em relação às mantidas por congregações de confessionalidade católica como, por exemplo, a implementação da coeducação. Encontram-se nesta fase a Escola Normal Rural Presidente Getúlio Vargas e a Escola Normal Rural Assis Brasil, de Três de Maio e de ljuí, respectivamente.

\footnotetext{
${ }^{1}$ Os dados coletados nas pesquisas, apoiadas pelo CNPq, que dão suporte a este texto demonstram que o recurso do exemplo de professores mais experientes foi extensivamente utilizado inclusive por escolas de confessionalidade católica.

2 Uma versão deste artigo foi apresentada no $6^{\circ}$ Congresso Brasileiro de História da Educação, realizado na Universidade Federal do Espírito Santo em maio de 2011, integrando a comunicação coordenada intitulada: Associações de alunos e imprensa estudantil.
} 
Vale lembrar que a formação de professores no Brasil, no início do século 20, ocorria de forma descentralizada. Apenas em $1946^{3}$, com a Lei Orgânica do Ensino Normal, se articula uma proposta nacional para a formação de professores. Com as reformas dos anos 1940, os cursos normais rurais passaram a ser designados de Normais Regionais, conforme a lei n. 8.530/46.

Estudo de Lourenço Filho (2001) demonstra a desigual distribuição dos cursos normais regionais entre os diferentes Estados do país. Informa que, em 1951, 34\% dos cursos normais regionais situavam-se em Santa Catarina, $10 \%$ no Ceará, em Minas Gerais $9 \%$ e em Pernambuco também 9\%, enquanto que os demais Estados apresentavam um número bem menor desses cursos. No Rio Grande do Sul apenas dois eram citados: os de escolas públicas situadas em Osório e Santa Cruz do Sul, criados na década de 1940 , representando $1,8 \%$ de todos os cursos regionais do país. O governo federal ignorava, portanto, a iniciativa privada na formação do professor rural do Rio Grande do Sul, na medida em que apenas registrava as duas escolas normais rurais criadas pelo governo estadual, sem assinalar as mantidas por iniciativa particular. Sabese, entretanto, que no período de 1934 a 1945 cinco escolas normais rurais foram criadas pela iniciativa privada no Rio Grande do Sul, com especial destaque para as escolas criadas ou administradas por congregações de confessionalidade católica.

\section{Caracterização do espaço institucional em que surgiram os impresso analisados}

As primeiras escolas normais rurais do Rio Grande do Sul constituem espaço específico de formação de homens para o magistério, o que diferencia a escola normal rural das demais escolas normais que atendiam ao público predominantemente feminino e voltado para as características da vida urbana. Essa formação do professor primário masculino em escolas católicas estava vinculada à necessidade de estancar o êxodo para as zonas urbanas e à importância de desenvolver lideranças rurais que promovessem a utilização de tecnologias mais avançadas para o trabalho rural.

Além do prédio escolar, também contemplavam os espaços escolares uma área para plantação de hortifrutigranjeiros e de criação de animais de pequeno e grande porte, que auxiliavam na auto-suficiência da comunidade educativa. Era intensa a integração com a comunidade regional por meio da participação em exposições e festas específicas das áreas rurais como, por exemplo, exposição de suínos, festa do milho. Se a formação teórica era predominantemente evangelizadora, as atividades práticas consistiram no conhecimento, sob a supervisão de um mestre mais experiente, de atividades voltadas

\footnotetext{
${ }^{3}$ A lei n. 4024/62 instituiu o ensino primário de quatro séries e o ensino médio subdividido em ciclo ginasial de quatro séries e ciclo colegial de três séries. Estes dois ciclos marcavam a estrutura de todos os ramos de ensino. Eram ramos de ensino o secundário, voltado para estudos propedêuticos e subdividido em ginásio e colegial com orientação clássica e colegial com orientação cientifica; o normal, que no primeiro ciclo formava o regente do ensino primário nos Cursos Normais Regionais e, no segundo ciclo, o professor primário; o ramo agrícola, constituído de ginásio agrícola e colegial agrícola com técnico em agricultura, técnico em pecuária; o ramo industrial, que no $1^{\circ}$. Ciclo tinha o ginásio agrícola e no segundo ciclo o técnico em mecânica, o técnico em eletrotécnica, etc; e o ramo comercial, com o ginásio comercial e o Técnico em Contabilidade, Técnico em Secretariado no segundo ciclo. Apenas na década de 1950 foram criadas duas escolas normais regionais pelo governo estadual no Rio Grande do Sul: uma Osório e outra em Santa Cruz do Sul.
} 
para o meio rural. A fé e o preparo agrícola marcam, portanto, a cultura escolar das escolas normais rurais masculinas da década de 1940.

A Escola Normal Rural La Salle, situada em Serro Azul, atual Cerro Largo, município situado a 515 km de Porto Alegre, uma zona de colonização alemã, mantida por irmãos Lassalistas, funcionou de 1941 até 1972. Nesse período diplomou 493 professores para as regiões Nordeste, Missões e Campanha do Rio Grande do Sul. Atualmente, esta instituição escolar lassalista é chamada de Colégio Medianeira ${ }^{4}$.

Figura 1

Fachada da Escola Normal Rural La Salle de Cerro Largo.

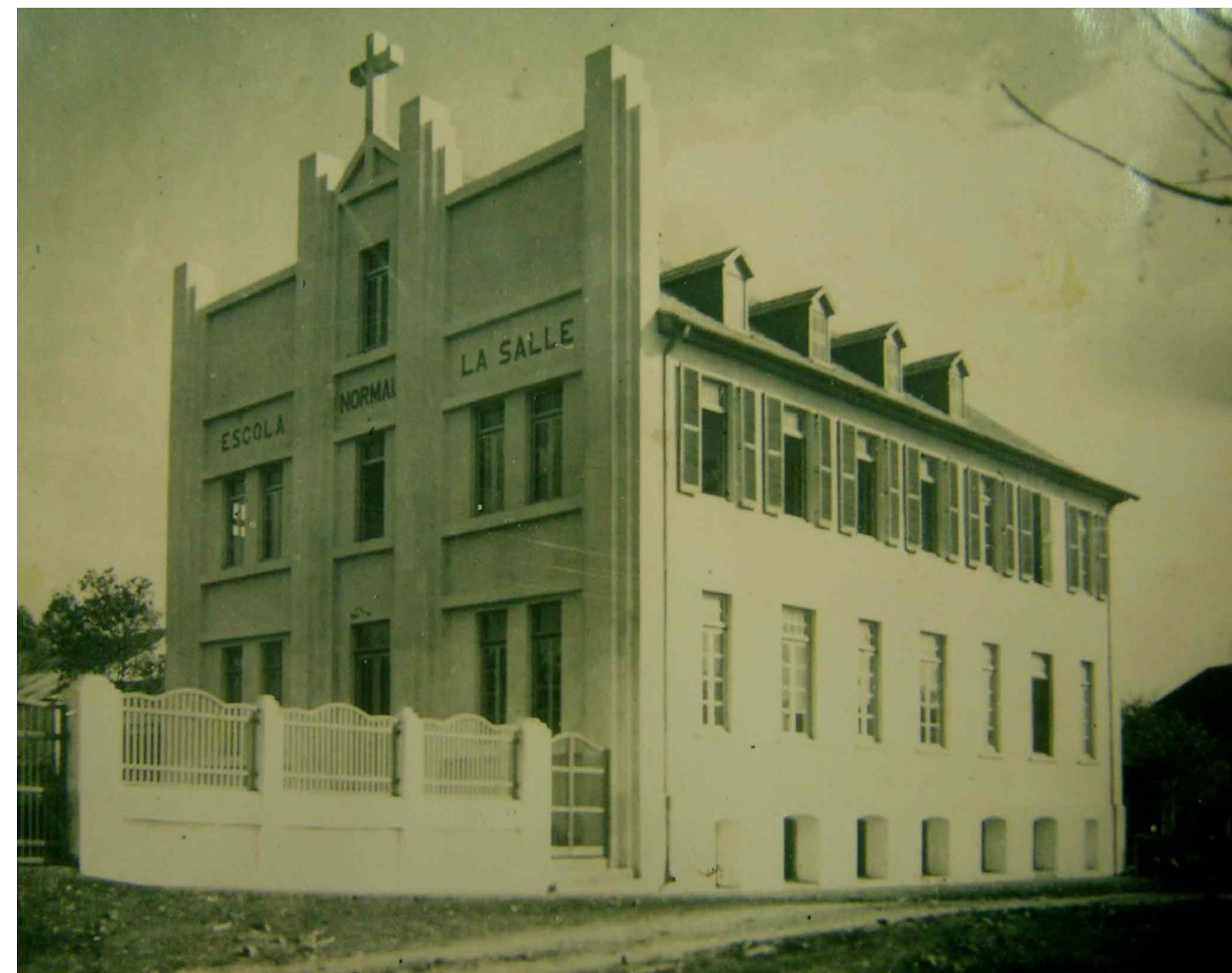

Fonte: Acervo do Colégio Medianeira de Cerro Largo, RS.

\begin{abstract}
${ }^{4}$ Chegados em 1907 ao Brasil, vindo diretamente para Porto Alegre e tendo já fundado uma dezena de estabelecimentos no Rio Grande do Sul, os lassalistas instalaram-se em Serro Azul. Isso ocorreu em 1935, quando assumiram a Escola Sagrada Família, paroquial, em funcionamento desde 1902. Na ocasião, foi assinado um convênio entre a Sociedade Católica de Serro Azul e os lassalistas, pelo qual se assegura, dentre outras condições, o respeito à cultura e às tradições alemãs da localidade, com o compromisso de manter a continuidade do ensino em língua alemã. Para atender a necessidade de oferecer o ensino secundário aos filhos de colonos, foi fundado, em 1938, um internato e, em 1941, a Escola Normal Rural La Salle, em convênio com o governo do Estado do Rio Grande do Sul. Esse curso normal rural funcionou até 1972 quando a Escola Normal Rural La Salle fechou. Em seu lugar foi criada a escola de Educação Básica La Salle Medianeira. Os lassalistas constituíram, em 1959, nessa mesma cidade, o Ginásio Medianeira, transformado, no ano de 1969, em Colégio Medianeira.
\end{abstract}


A outra escola cujos impressos estudantis são analisados neste artigo é a Escola Normal Rural Presidente Getúlio Vargas. Situada em Três de Maio, a 470 km da capital, na região do Alto Uruguai, Noroeste do Estado, essa escola foi criada em 1957 e ocupava uma área de terra de $80.000 \mathrm{~m}^{2}$. Em 1971 foi fechada como escola de formação de professores e transformada em Colégio Presidente Getúlio Vargas. Oferecia o Curso Técnico em Agropecuária. Sua história está ligada às iniciativas educacionais de imigrantes alemães de confessionalidade evangélica luterana, vinculados à Igreja Evangélica de Confissão Luterana no Brasil que, desde a década de 1920, mantinham uma escola de comunidade. A instalação da Escola Normal Rural Getúlio Vargas, em Três de Maio, contou com recursos concedidos pelo Instituto Nacional de Estudos Pedagógicos e decorreu da iniciativa da comunidade e políticos da região. Admitia alunos em regime de internato, mas também havia um internato feminino de moças que procuravam o curso de formação de professores rurais. A primeira turma de professores rurais titulou-se em 1961.

Figura 2

Fachada da Escola Normal Rural Presidente Getúlio Vargas.

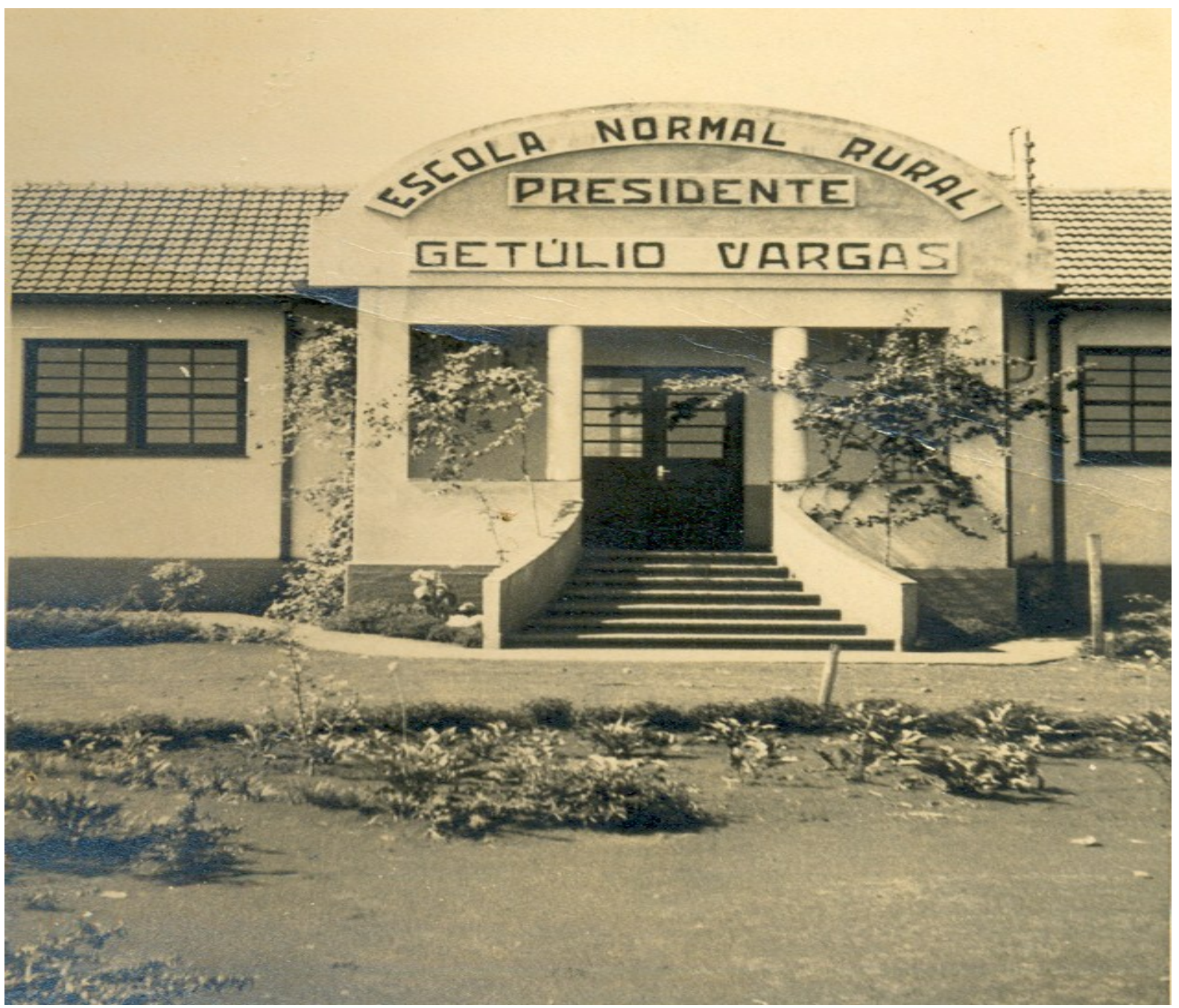

Fonte: Acervo da Sociedade Educacional Três de Maio, RS. 


\section{Os periódicos analisados}

O primeiro periódico analisado é $A$ Voz da Serra, dos alunos da Escola Normal Rural La Salle, de Cerro Largo, que foi publicado no período de 1946 a 1950. O outro periódico analisado - O Eco do Estudante -, órgão dos alunos da Escola Normal Rural Getúlio Vargas, de Três de Maio, impresso criado em 1957, é analisado considerando-se a estrutura, condições de produção, imagens e conteúdo do impresso. As fontes deste estudo são exemplares dos impressos localizados nos arquivos destes estabelecimentos de ensino, embora as escolas normais rurais nas quais eles foram produzidos tenham sido extintas no início da década de 1970.

Na Escola Normal Rural La Salle o impresso foi vinculado ao Grêmio Literário La Salle e, depois, à associação de alunos da escola, a qual não se declarava com objetivos exclusivamente literários, pois as atividades esportivas tinham grande relevância na escola e na comunidade, o que também transparecia nos objetivos do impresso estudantil. Vários foram os títulos desse impresso: Crônicas, A Voz da Serra, O Normalista Rural. A partir de 1956 passou a se denominar O Ruralista, transformando-se em informativo oficial da União Estudantil Cerro-Larguense, instituição de coordenação dos estudantes de Cerro Largo e não apenas dos alunos da Escola Normal Rural La Salle. Os 57 exemplares analisados foram localizados no Colégio Medianeira, nome atual do colégio lassalista de Cerro Largo.

\section{Quadro 1}

Imagens dos títulos do impresso estudantil da Escola Normal Rural La Salle, Cerro Largo, RS.

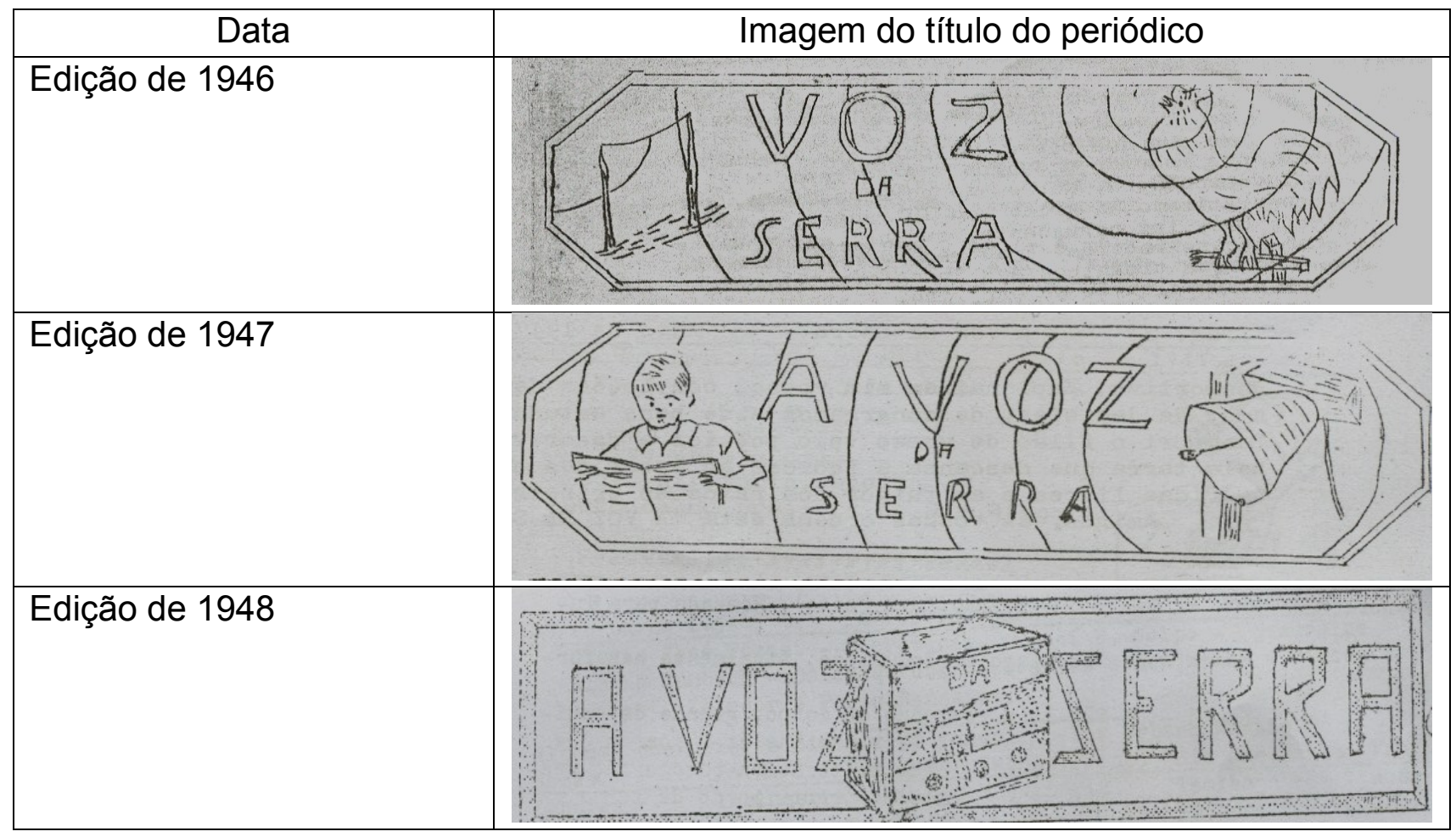




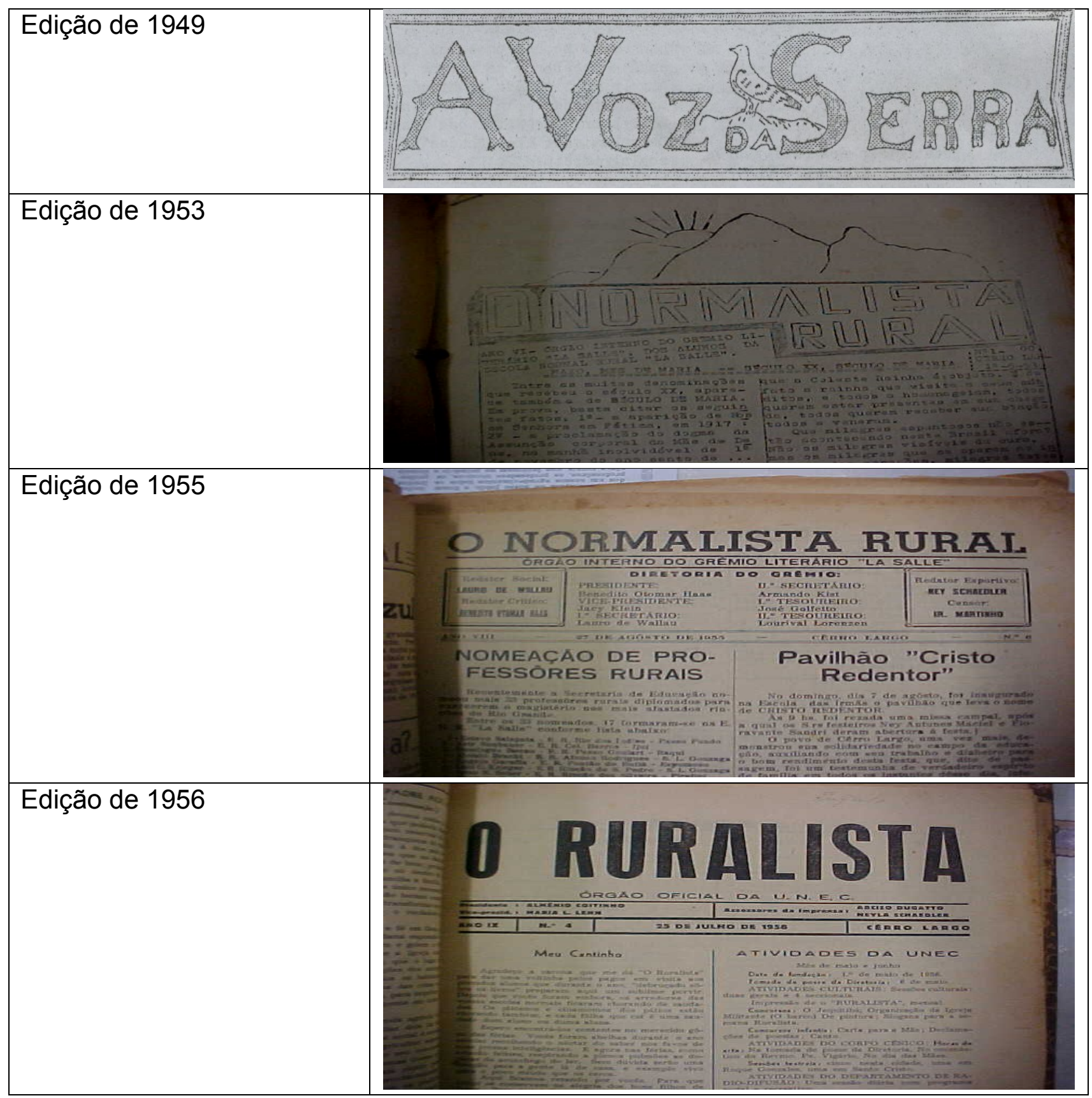

Este artigo também analisa o impresso dos alunos da Escola Normal Rural Presidente Getúlio Vargas, de Três de Maio. São considerados 28 exemplares do impresso estudantil O Eco do Estudante, criado em 1957 como informativo oficial do Grêmio Estudantil Duque de Caxias. Foram localizados e analisados os números publicados de 1962 a 1983. No período de cinco anos, de 1962 a 1966, dispomos de dezesseis exemplares; entre 1971 e 1975 analisamos seis exemplares, de 1979 a 1983 analisamos quatro exemplares. Em 1977 há um exemplar. Não dispomos da série completa do impresso, por isto não temos nenhum exemplar dos anos de 1967 a 1970, 1974, 1976, 1978, 1979, e 1981. No caso desta escola, o impresso não sofreu alterações em sua designação. Como era feito artesanalmente, com os recursos de mimeógrafo à tinta, a forma de grafá-lo alterou-se como pode ser observado a seguir. 
Quadro 2

Imagens dos títulos do impresso estudantil da Escola Normal Rural Presidente Getúlio Vargas.

Data
Edição de maio de 1962,
1a. Edição
Edição de maio de 1964 Ingem do título do periódico
Edição de outubro de

Descrevemos, anteriormente, os dois momentos iniciais de exploração do material empírico. Foram fases de reiteradas leituras, inclusive no sentido de apreender o conteúdo dos impressos. Foi quando mapeamos as temáticas em algumas categorias as quais apresentamos a seguir. Destacamos que o objetivo deste artigo não é realizar um trabalho comparativo entre os impressos das duas escolas normais rurais. A tabela que segue, entretanto, indica a presença de temas comuns em ambos. 
Tabela 1

Percentagem de temas presentes os impressos estudantis das escolas normais rurais La Salle e Presidente Getúlio Vargas.

\begin{tabular}{|l|c|c|}
\hline \multicolumn{1}{|c|}{ Categorias } & Impresso da ENR La Salle & Impresso da ENR Getúlio Vargas \\
\hline Humorismo/curiosidades & $18 \%$ & $30 \%$ \\
\hline Social & $23 \%$ & $10 \%$ \\
\hline Religião & $10 \%$ & $11 \%$ \\
\hline Esporte & $10 \%$ & $4 \%$ \\
\hline Escolar & $17 \%$ & $17 \%$ \\
\hline Formação do professor & $2 \%$ & - \\
\hline Propaganda & $14 \%$ & - \\
\hline Ruralismo & $3 \%$ & $4 \%$ \\
\hline Poesia & - & $11 \%$ \\
\hline Pensamentos & - & $7 \%$ \\
\hline Outros & $3 \%$ & $6 \%$ \\
\hline Total & $100 \%$ & $100 \%$ \\
\hline
\end{tabular}

Como identificado em artigo anterior (Werle, Brito, Nienov, 2007), várias pesquisas acerca de impressos estudantis registram a presença de matérias de conteúdo que aqui chamamos de humorísticos. Sousa (1997), ao analisar a revista escolar Auxilium, do Colégio Santa Inês, publicada entre os anos 30 e 60 do século 20 destaca, dentre os conteúdos da revista, os concursos de problemas, adivinhações, perguntas, piadas, historinhas de fundo moral, charadas enigmáticas, desenhos que muito se aproximam do conteúdo que designamos de humorísticos. Amaral e Silva (2005), ao estudar a revista científica, didática e literária do Clube Literário da Escola Complementar de Pelotas/RS, mencionam seções com perfil humorístico, incluindo charadas, divertimento e zombarias com um "caráter bem humorado, com brincadeiras dirigidas às alunas, não escapando os professores e professoras, nem mesmo o diretor e inspetor escolar" (p. 2-3). Amaral (2002) também reporta que muitos jornais estudantis foram eliminados dos arquivos dos estabelecimentos por sua "irreverência e crítica através, principalmente, de representações satíricas e caricaturizadas da sociedade, da escola de professores e de alunos" (p. 123).

\section{Impresso da Escola Normal Rural La Salle de Cerro Largo}

O impresso estudantil da Escola Normal Rural La Salle foi criado em 1945 com o nome de Crônicas. No ano seguinte o nome do impresso foi alterado para Voz da Serra. As imagens que acompanhavam o título relacionavam-se com sons: galo cantando, um menino lendo e um sino, um rádio, uma ave ou, sem figuração decorativa, apenas o título.

O Voz da Serra apresentava-se como órgão interno da escola, passando, em 1948, a se anunciar como órgão interno dos alunos da escola, ocasião que teve seu título alterado para A Voz da Serra. Portanto, passaram-se três anos, desde sua criação, até que o impresso fosse definitivamente declarado como de autoria, origem ou representação do corpo discente. Curiosamente,parece ter ele passado de uma fase mais informal, até 1948, de manifestação livre dos alunos, para uma fase mais formal, em que 
as matérias eram mais seguidamente assinadas: seu conteúdo de mais coloquial e descomprometido, torna-se mais informativo, mais sério.

Por informalidade referimos matérias que expressam camaradagem, crítica a colegas, relatos de acontecimentos cômicos, anedotas inspiradas nas ocorrências do diaa-dia dos alunos na escola e o layout do impresso. Publicado mensalmente, o Voz da Serra, de aparência modesta, impresso em papel tipo jornal, era ilustrado com desenhos simples, contornos figurativos, muitos deles humorísticos, dentro das possibilidades que a tecnologia de mimeógrafo a tinta permitia.

Possivelmente, os desenhos eram feitos a mão livre, sem cópia ou fôrmas, muito caricatamente compareciam representações figuradas de pessoas, seus cacoetes e dos acontecimentos, articulando no contexto dos impressos outras formas de expressão acerca das práticas e do imaginário escolar, uma forma alegórica e permeada de ironias. O jornal era um espaço de criação estudantil e de experimentação de formas e desenhos para expressar as relações escolares. As várias caricaturas dos colegas e a forma jocosa de representá-los sugeria uma vida com brincadeiras simples que ocorriam no cotidiano. As expressões que acompanhavam estas figuras eram breves, mas sugestivas.

O impresso de maio de 1949 indicava o nome do desenhista, dentre os que trabalharam como colaboradores, o que demonstra a importância do mesmo para a confecção do impresso. Os desenhos eram valorizados e, geralmente, acompanhados de observações, como se fossem breves legendas.

As diferentes seções também recebiam desenhos alusivos que foram sendo rearticulados ao longo dos diferentes números. São exemplos disso as seções Tesoura da comadre, Esportes e Agrícola. Há charges sobre o próprio jornal a respeito de sua leitura e distribuição, divulgação na comunidade. Várias representações humorísticas são a respeito dos alunos em atividades escolares: preparando-se para exames e provas, para a formatura ou envolvendo-se em atividades agrícolas. Os alunos representavam aspectos pitorescos de si mesmos, captando suas características, as formas de se expressar e de viver os acontecimentos, as especificidades e maneirismos que cada um trazia como marca de sua região ou origem étnica-familiar. O impresso era um espaço de expressão das disputas entre os alunos como, por exemplo, a seção intitulada Detetive dos externos. A seguir apresentamos algumas caricaturas referentes às férias que se apresentam em várias edições dos impressos.

\section{Quadro 3}

Excertos do impresso estudantil da Escola Normal Rural La Salle de Cerro Largo, RS.

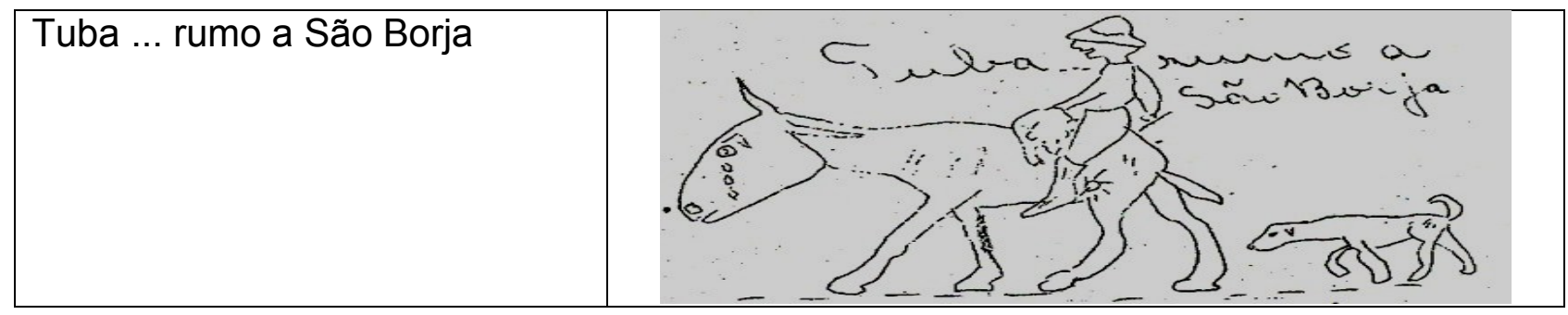




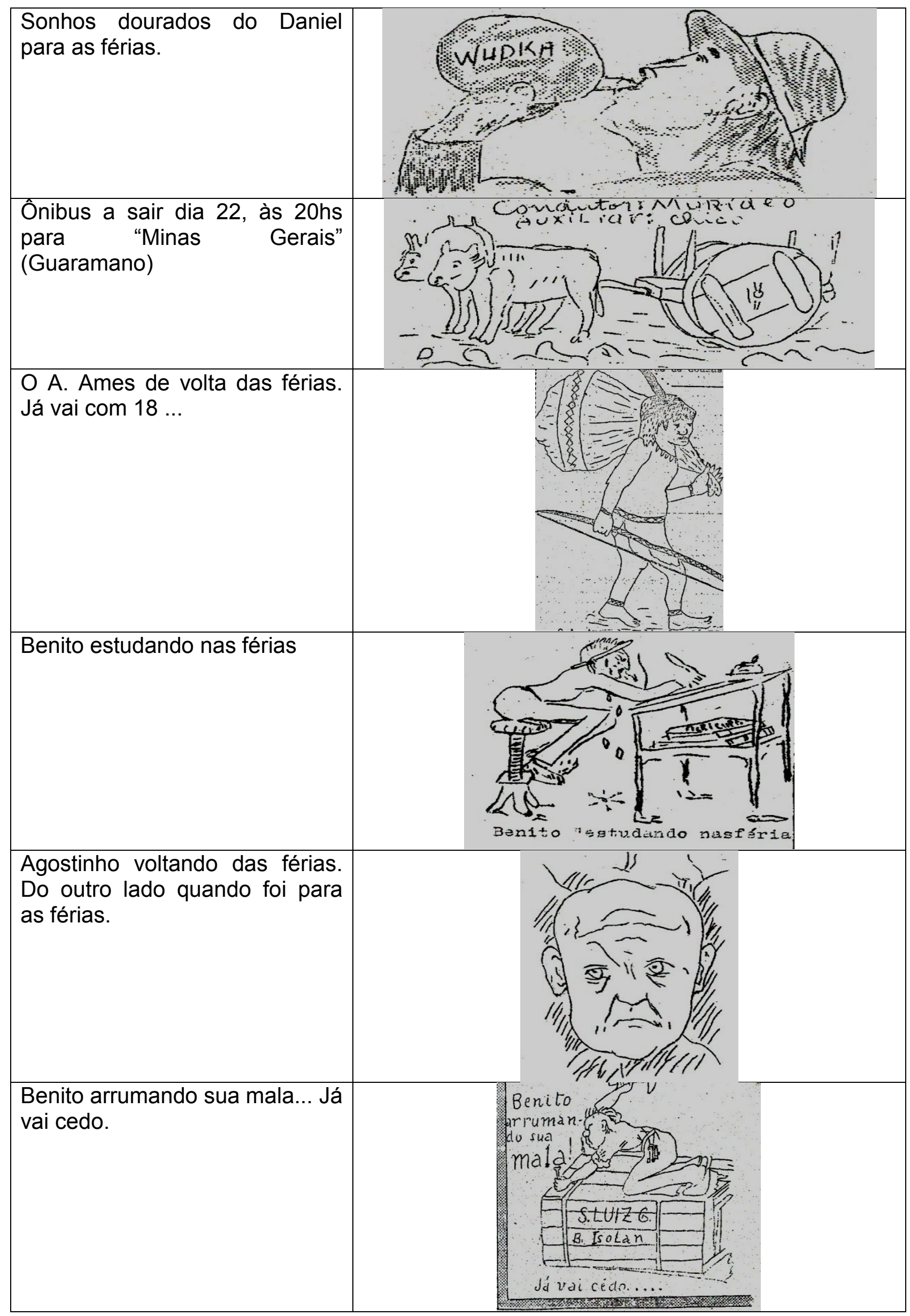




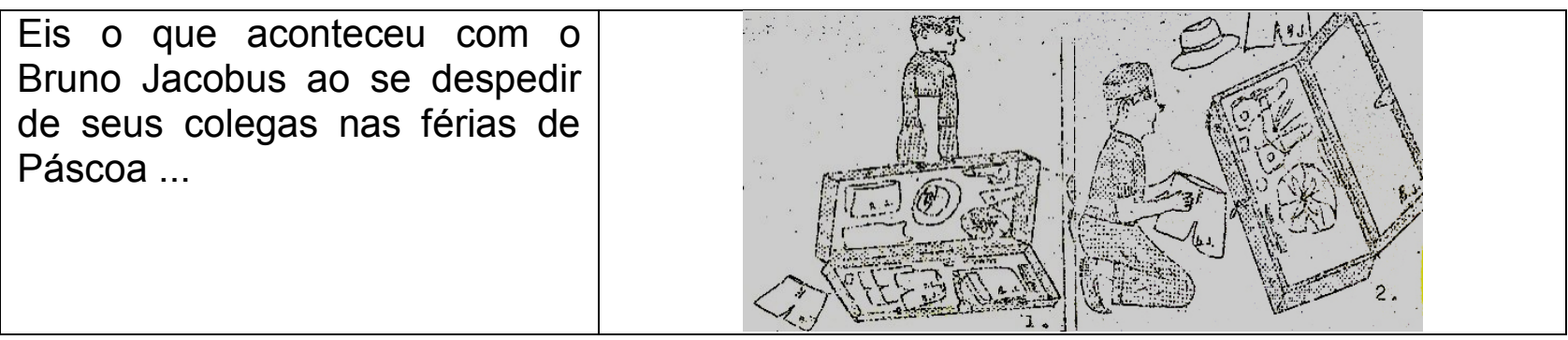

A seguir, algumas das observações que acompanham os desenhos e caricaturas do impresso A Voz da Serra: Quem interpreta esta do Helio? - Na duvida? Eu sou o pipa. Jacó vindo para a aula (imagem de um rapaz sentado numa vassoura com um livro na mão), - Agostinho voltando de férias. - Arno e Jung preparando o exame. Que coisa! Auto retrato de José Kisiel em trajes de caça. Belo tipo de Tarzã .. de cueca (figura de um rapaz de estilingue na mão, camiseta de física e calção) . - S.F. numa corrida de vida ou morte (figura de um rapaz correndo com vidros na mão e um porco o perseguindo) Qualquer semelhança com L.M. é mera coincidência. - Benito estudando nas férias. Sady no trem admirando a natureza. - Furo fotográfico: técnico ensaiando a formatura. Método de ordenhar por semelhança adaptado com eficiência na estância do Adão Formiga.

Muitas temáticas estavam envolvidas: férias, preparação para os exames e a exigência de estudos, futebol, visitas técnicas, disputas entre internos e externos.

A figuração dos esportes ${ }^{5}$ enfatizava o futebol. Havia, por exemplo, desenhos que, ao lembrar o jogo de futebol em que o time não venceu, o técnico é representado de cabeça inchada e o dístico "DHS voltando de um encontro futebolístico". Ou outra imagem em que o amor pelo Aurora, time da cidade, é representado por colegas abraçados dançando e entoando uma música carnavalesca que fala de uma mulher de nome Aurora, mas que eles integram na charge fazendo referência ao time de futebol de mesmo nome "veja só que bom que era, Óóó oh!! Aurora". Ou ainda, a figura de um mendigo sentado no chão pedindo esmola com chapéu na mão e o dístico: "o torcedor - agora me convenço que não adianta torcer contra o Aurora".

Vale lembrar que numa certa época foi criada uma seção chamada a Tesoura da comadre, em que havia uma tesoura desenhada cortando uma fita onde se lia "vida alheia". Neste espaço, mas não apenas restritas a ele, encontravam-se as caricaturas, desenhos humorísticos e imagens de críticas de colegas e fatos escolares.

Vale lembrar que nem todas as charges designavam claramente a pessoa retratada, pois em vários casos eram utilizadas as iniciais. Em uma escola que funcionava em regime de internato a convivência era intensa, pois os estudantes voltavam muito raramente para suas casas e todos se conheciam de forma que, entre si, os estudantes compartilhavam as chaves interpretativas das imagens humorísticas e críticas dos colegas e situações.

\footnotetext{
${ }^{5}$ Em Werle (2011) discutimos as práticas esportivas em escolas normais rurais e referimos a influência da Escola Normal Rural La Salle na fundação do Esporte Clube Aurora de Cerro Largo.
} 
Da análise do impresso estudantil da Escola Normal Rural La Salle de Cerro Largo pode-se inferir que o impresso era um espaço de expressão das alegrias, das percepções, das disputas dos alunos e da forma destes se relacionarem com os acontecimentos, inclusive com as formaturas e fatos escolares. O impresso Voz da Serra constitui-se nas charges, nos desenhos humorísticos em espaço de recontextualização das situações vividas, tanto das originárias do currículo escolar, como das decorrentes dos relacionamentos entre os alunos e das atividades de lazer.

\section{O Eco do Estudante: impresso estudantil da Escola Normal Rural Presidente Getúlio Vargas de Três de Maio}

O jornal da Escola Normal Rural Presidente Getúlio Vargas é também um impresso modesto em seu aspecto físico. Criado em 1957 como informativo oficial do Grêmio Estudantil Duque de Caxias da Escola Normal, apresentava desenhos e imagens para decorar as páginas e marcar as diferentes seções. Os desenhos, entretanto, aparecem bem mais restritamente do que no outro impresso analisado. As imagens não eram caricaturas, charges; predominavam as de cunho apenas ilustrativo. Chama a atenção o número de matérias assinada pelos alunos, com a indicação do nome e série dos autores.

O jornal O Eco Estudantil trazia sempre um tema de capa, de cunho formativo ou cívico. São exemplos de temas de abertura: Conceitos de paz, Educação de adultos, Revolução de 31 de março de 1964, Cristianismo, Epopéia dos pioneiros - dia do colono -, Dia das Nações Unidas, Despedida (edição extra em que cada turma de alunos da escola escreve uma mensagem de uma pagina para os formandos da escola), Liberdade como unidade de direito, Treze de maio, Batalha do Riachuelo, Quem for brasileiro siga-me, Ludwig Von Beethoven, O cão através dos tempos, Energia, Meio ambiente, Fraternidade, bem como propostas da diretoria do impresso. Vários conteúdos desta seção de abertura do jornal eram transcrições de trechos de livros, bem como havia também matérias de capa assinada pelos alunos; neste caso os temas eram mais diretamente ligados à vida dos alunos (A cola, O líder, Nosso jornal).

Havia um suplemento rural no qual se abordavam temas como: plantio em curvas de nível, cultura do arroz, agricultura e aliança para o progresso, húmus na agricultura, cultura do solo, baixa produtividade dos feijoeiros.

Dentre as seções do impresso estavam Humorismo, Aniversariantes, Você Sabia?, Palavras cruzadas, Poesias, Noticiário escolar, Crônica esportiva, Palavra ao leitor, Cultura geral. Na seção Cultura geral vários eram os temas abordados: cinema, primavera, pobreza. Não havia, entretanto, muita regularidade e presença dessas seções em todos os números das seções do periódico. 
Quadro 4

Imagens que decoravam as seções do impresso estudantil da Escola Normal Rural Presidente Getúlio Vargas de Três de Maio, RS.

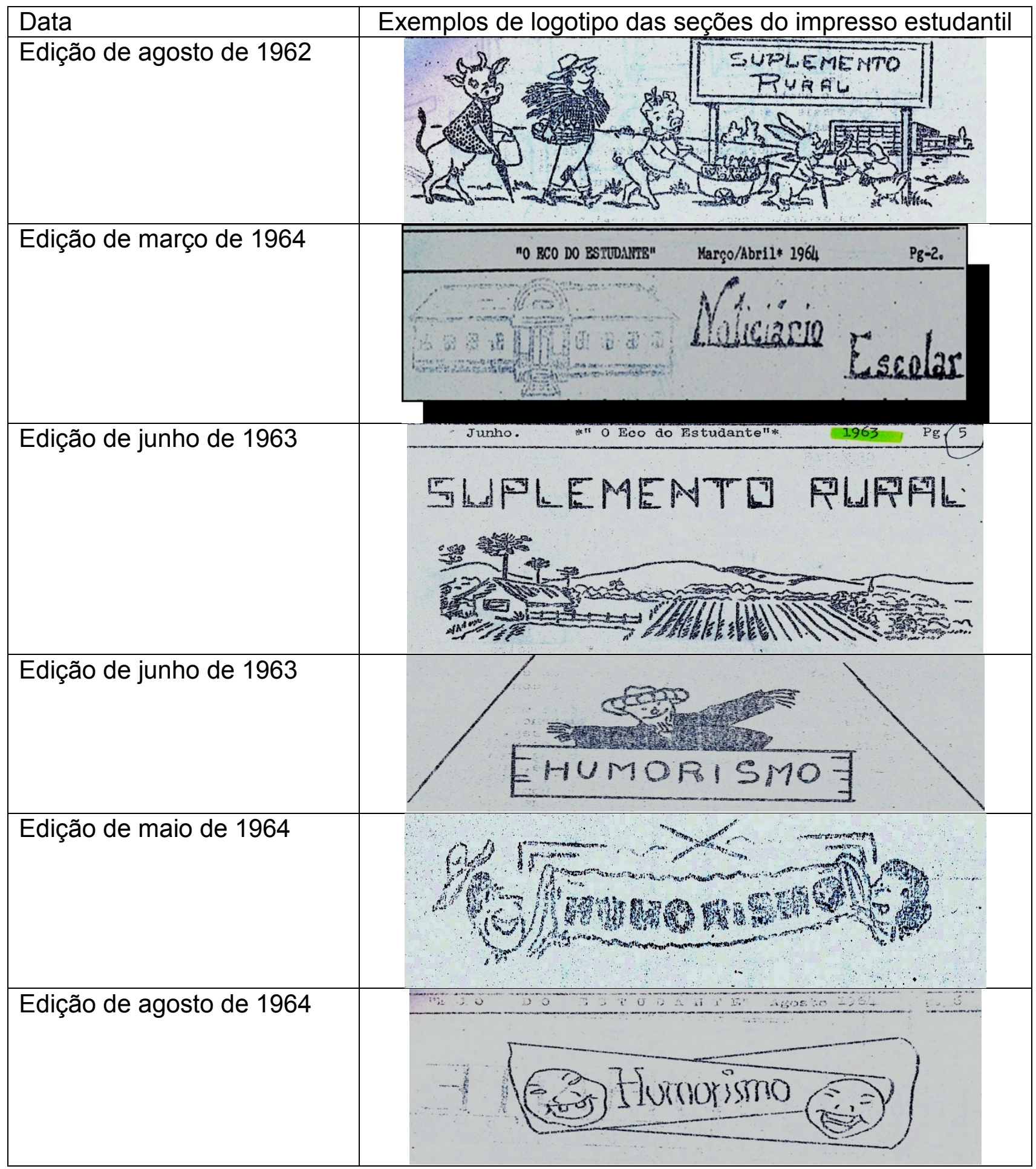




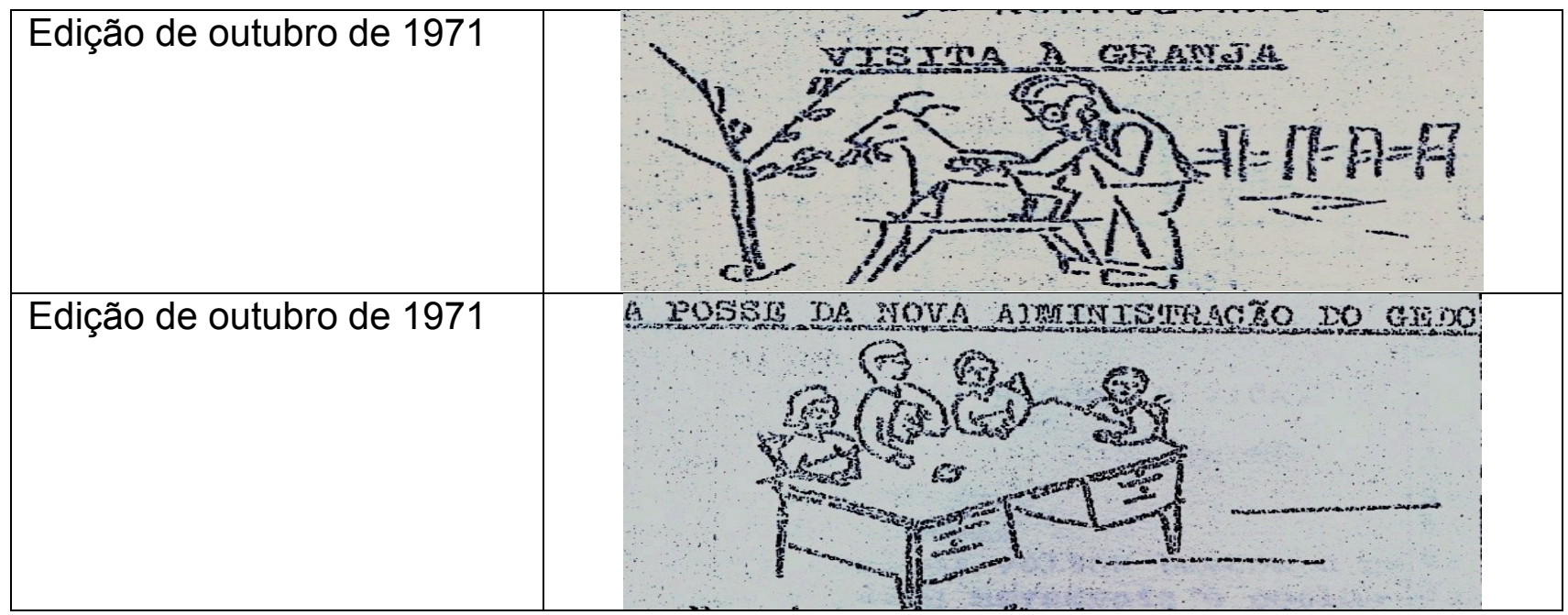

O conteúdo do impresso demonstrava um corpo discente e um grupo de editores bastante críticos. Referências à acontecimentos ocorridos no dormitório, disputas entre diretorias do Grêmio Estudantil, observações a respeitos de namoradas e mulheres, críticas aos colegas, disputas esportivas, reações a atividades curriculares, destaques à importância de apoiar ao Grêmio eram registrados por escrito, embora sem imagens ilustrativas. O conteúdo de crítica era bastante acentuado neste impresso. Alguns comentários sobre os colegas eram rebatidos em números subseqüentes, com réplica e tréplica. Havia também mensagens aos formandos enviadas por alunos das diferentes turmas da escola, assim como despedidas assinadas e, individualmente, escritas pelos que estavam concluindo seu curso.

A seguir alguns trechos do Eco Estudantil, organizados em seis temas articuladores: dormitório, esportes e disputas esportivas, grêmio estudantil, mulheres, atitudes femininas e namoradas, estudos e atividades escolares e temas gerais. Em geral iniciavam assim: Tu sabias ... ou, Lembrete.

\section{Quadro 5}

Excertos do impresso estudantil da Escola Normal Rural Presidente Getúlio Vargas.

\begin{tabular}{|c|c|c|}
\hline $\begin{array}{l}\ldots \text { que segundo já } \\
\text { podíamos constatar muitos } \\
\text { pensam que não precisam } \\
\text { mais colaborar com o } \\
\text { Grêmio, nem a } \\
\text { mensalidade não querem } \\
\text { pagar. O que são vocês? } \\
\ldots \text { Alguns associados do } \\
\text { Grêmio acharam } \\
\text { conveniente expressar um } \\
\text { pouco melhor as gracinhas } \\
\text { do Horst. Portanto resta- }\end{array}$ & $\begin{array}{l}\text { ¿e o Buth estava com } \\
\text { ide de tontear os seus } \\
\text { sários a base de } \\
\text { etes" no jogo de vôlei } \\
\text { a o Monteiro Lobato. } \\
\text { e há gente que é capaz } \\
\text { acrificar a vida somente } \\
\text { conquistar uma } \\
\text { íada, uma medalha? } \\
\text { e o A.P. numa palestra } \\
\text { colegas deu por } \\
\text { der que está } \\
\text { encido de que é um }\end{array}$ & $\begin{array}{l}\text {... que a C.M.M. vive consultando } \\
\text { revistas nas quais encontra } \\
\text { estrelas do cinema e, depois } \\
\text { procura imitá-las em todos os } \\
\text { meios alcançáveis aqui na G.V. } \\
\ldots \text { que o centro de encontros } \\
\text { amorosos é a popular sala de } \\
\text { leitura. } \\
\ldots \text { que nas férias de Páscoa o } \\
\text { Edilso tinha ido a Tenente Portela } \\
\text { para ali desfrutar, no namoro, os }\end{array}$ \\
\hline
\end{tabular}


ignorante, pois queria impor costumes nos outros que nem a si pode corrigir. Rifase também, agora, a ignorância do Horst.

... que o nosso Grêmio demitiu-se da União

Tresmaiense de Estudantes Secundários e com isso a mesma decaiu completamente dias após esse acontecimento.

...Alguns associados do Grêmio que realmente se preocupam com o bom funcionamento do mesmo e para que este não passe de um monte de cinzas frias, dão um voto de louvor ao Dir. Cultural porque ele não deixou apagar as brasas e muito menos permaneceu parado. Outrossim afirmam que o nosso Grêmio jamais possuiu um igual ao de hoje. Disso poucos duvidam, muitos concordam.

... O Lena, papudo como ele é, quis bancar o importante quando apareceu a rifa na qual sua bela moreninha era a vítima. Além do mais, ofendeu-se declarando que o autor deveria se acusar. Ele, porém não se lembrou que tempos antes era ele, e muito menos também se acusou, que participava do trio de "traidores" dos "mascarados" que levou à derrota o Irineu.

.. Não adianta achar ruim seu Donimo. Porque não pediste dinheiro para organizar o torneio de Spiriboll quando eras o primeiro secretario do Grêmio? Certamente recém agora queres realizar alguma promoção, quando estás com o bigodinho crescido! bom corredor. Após uns colegas tinham dado umas "risadinhas" da sua "furada" quis matar o Heinsch por terlhe revelado a verdade.

Durante uma brincadeira de basquete o I.V. muito se admirou com a presença do Lambari, Coelho, Pintado e do Piranha, porem só no fim se lembrou que também havia um Caxingelê em campo.

... que alguém está fazendo um time de vôlei em secreto, só para também jogar.

... que as moças da normal venceram uma partida de vôlei contra o Comercial Schneider Logemann de Horizontina. Sabem por que? Porque jogaram de "slaque".

... que em Horizontina, o Heinsch venceu a grito o jogo de basquete contra o Ginásio Ipiranga de Três Passos. encontrou ali um incrível numero de rivais.

...que já foi constatado que a celebre frase do dia 14 de outubro de 1965: "A partir de hoje o namoro está terminantemente proibido" ainda não surtiu efeito.

... que a N.V., conforme fomos informados, dorme cada noite com uma boneca a seu lado. Que criancice!

... que algumas moças pintam-se tanto que o efeito é negativo: tapam o que de bonito ainda havia!

... que a C.M.M. após um encontro com o seu "preferido" vira uma fera danada; dá coices para tudo que é lado. Tomem providencias! ...que numa partida de vôlei o Edison olhou nada menos que 102 vezes para a G.M.M. Este sujeito deve estar mergulhado na paixão. Será que ele não desconfia da própria sorte?

O Affonso ao ser alvo de caçoada de umas moças, sobre piadas a seu respeito no jornalzinho, assim se expressou: "É vocês têm inveja que não podem namorar comigo". Isto demonstra que ele acha que suas obras e os seus "Patsch" tem alguma coisa de lógica e nexo. 


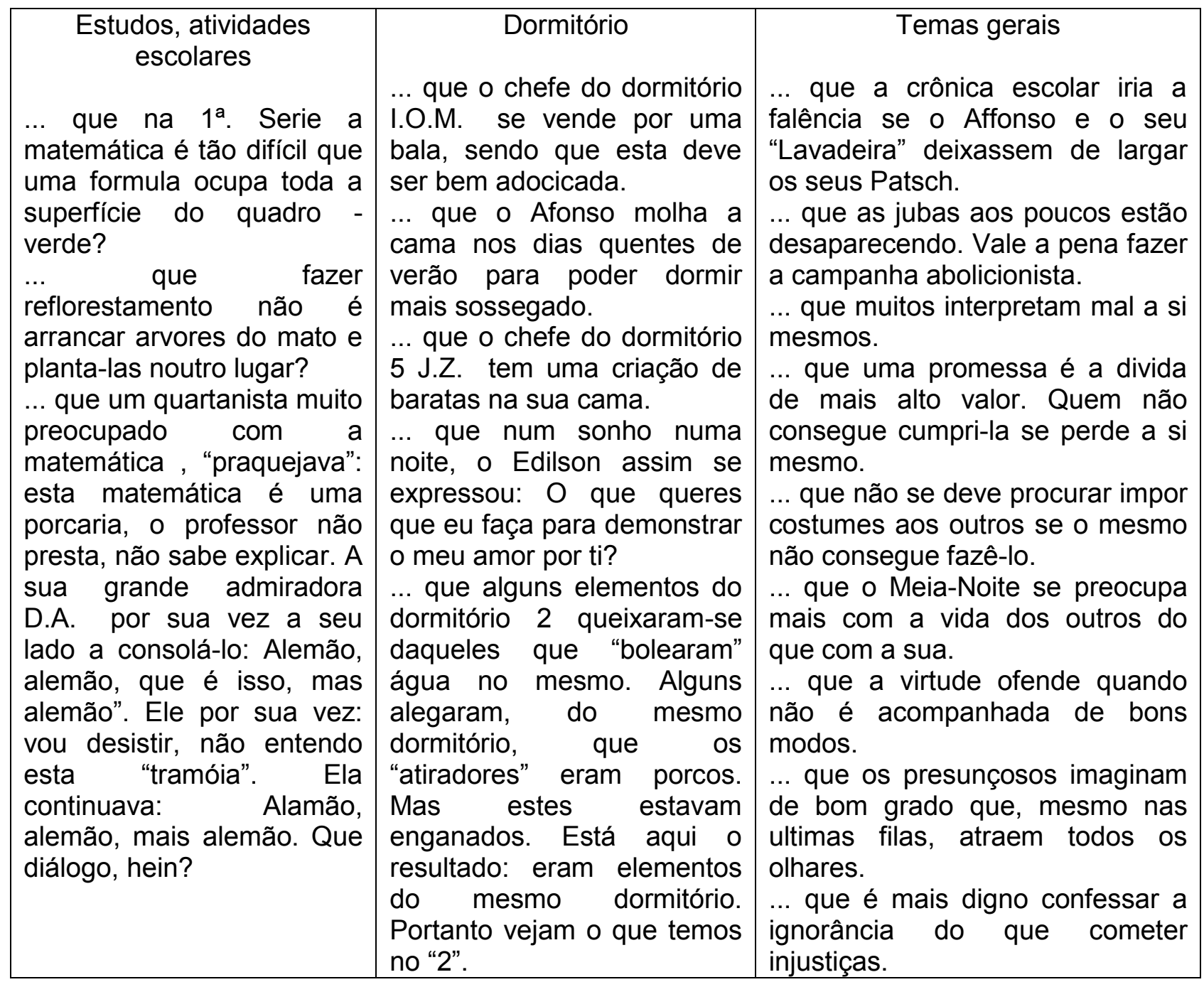

Os trechos indicados acima registram, em sua maioria, críticas entre pares, ou seja, alunos que ridicularizavam, faziam chacota de hábitos, defeitos, lapsos, gostos, atos, erros de fala de seus colegas. O emprego de apelidos é uma constante. As manifestações denotam, por vezes, preconceitos e críticas maliciosas a formas de se comportar dos colegas. Vários excertos põem em evidência vaidades de uns e outros, ironizam estratégias de articulação política entre os grupos. Há também os que demonstram, de forma divertida, o não cumprimento de normas da escola. Marcante é, também, as críticas a componentes de outras gestões do Grêmio Estudantil ao indicar a inércia de outras diretorias.

O Eco Estudantil, da Escola Normal Presidente Getúlio Vargas, apresenta-se como um impresso cujas matérias são assumidas pelos alunos e cujo conteúdo é fortemente marcado pela crítica e disputas. As imagens figuram restritamente, mas a crítica a todos os momentos de vida em comum no internato está presente em todos os números. $A$ autoria é marcada por meio da escrita de poesias assinadas, textos assertivos sobre temas e literatura consultada. Entretanto, é possível constatar como as vozes femininas são silenciadas. Embora seja um colégio misto em que moças e rapazes estudavam 
juntos em um mesmo curso, elas são motivos de troça e gozação, mas não se pronunciam como autoras das críticas.

\section{Elementos conclusivos}

Pela análise do impresso escolar $A$ Voz da Serra pode-se afirmar que o perfil de professor rural era intencionado na instituição e reforçado nos conteúdos veiculados nesse impresso, que se tornava um instrumento para os objetivos da escola, da religião e da formação do professor rural. Por certo, os impressos estudantis eram uma estratégia para manter os alunos ocupados de forma ordenada e de prover mais um meio de fortalecer as propostas formativas da escola: religiosidade, emulação, conteúdo de formação e o disciplinamento.

A Voz da Serra desempenhava esse papel pelo destaque a jogos e esportes, pela divulgação de equipes mais fortes que ganhavam torneios e premiações, valorizando os grupos vencedores. Por outro lado, o impresso promovia as boas relações entre alunos e seus professores, divulgava os aniversariantes de um e de outro segmento escolar, anunciava o nascimento de filhos de professores, bem como o casamento de algum docente ou mesmo falecimentos. Abordava temas relacionados com a saúde e a higiene, com a formação religiosa e apresentava lições moralizantes e de cunho normativo.

O Eco de Estudante, publicado pelo Grêmio Estudantil da Escola Normal Presidente Getúlio Vargas de Três de Maio, apresenta-se como um impresso variado que expressava humorismo e leitura crítica das vivências no interior da escola, embora com restritos recursos gráficos. Os principais autores eram os rapazes, embora fosse mista a escola. $\mathrm{O}$ recurso do desenho era utilizado restritamente, mas os traços de humorismo para com as vivências diárias na escola eram expressos sistematicamente no jornal.

Pode-se afirmar que em ambos os impressos analisados havia espaço para expressão de uma cultura estudantil de posicionamento e não apenas de acatamento frente às redes de relacionamento e às normas escolares. Neles, os alunos manifestavam adesões e oposições a situações vividas dentro da escola. Num dos impressos os desenhos eram usuais e expressivos. Pela rusticidade, esses desenhos tornavam-se cômicos e as críticas mais leves, levando ao riso. Ora, sabe-se que o desenho fazia parte da proposta formativa do professor rural, mas os impressos estudantis situavam-se fora do currículo formal e a utilização de figuras desenhadas, representando cenas da vida escolar, exigia um traçado à mão livre, forte e vigoroso, ajustado à matriz de tinta com que a publicação dos alunos era impressa.

No impresso estudantil do outro estabelecimento, o recurso do desenho era raro mas, na escrita, os alunos teciam ironias, releituras de acontecimentos e ridicularizavamse mutuamente. Em ambos os casos ocorriam práticas de exercício da escrita e da leitura do mundo, de desenvolvimento literário mediante a utilização de linguagens diferenciadas. A forma de expressão nos excertos estudados não era marcada pela literatura tradicional, mas trazia para o texto uma linguagem coloquial, cotidiana. Os impressos faziam dos alunos entes visíveis dentro da escola, capazes de manifestações de autonomia e de formas diferenciadas de praticar. 
Os impressos estudantis analisados constituíam-se em espaços, pelo menos, parcialmente ocupados por estratégias de manifestação singulares aos alunos. Os impressos estudantis analisados afiguram-se como espaços de sociabilidade pela interação e apreciação acerca das formas de interação na escola e fora dela. As críticas formuladas constituíam tipos de estratégias de conformação de concepções e de comportamentos, dando a ver o que chamava a atenção, o que discrepava no conjunto das interações sociais, embora os impressos estudantis tenham sido tutelados por professores, o que se pode verificar pelas seções que os compõem, e pelo fato de que estes, às vezes, publicavam artigos.

\section{Referências}

AMARAL, Giana Lange. Os impressos estudantis em investigações da cultura escolar nas pesquisas histórico-institucionais. História da Educação, Porto Alegre: Asphe, v. 6, n. 11, 2002, p. 117-130.

AMARAL, Giana; SILVA, Daiani Santos da. Aspectos da cultura escolar veiculados pelo impresso estudantil Complementarista da Escola Complementar de Pelotas/RS. ENCONTRO DA ASSOCIAÇÃO SUL-RIO-GRANDENSE DE PESQUISA DE HISTÓRIA DA EDUCAÇÃO, 11, 2005, Pelotas, Anais ... Pelotas, 2005.

BASTOS, Maria Helena Câmara. As revistas pedagógicas e a atualização do professor: a Revista do Ensino do Rio Grande do Sul (1951-1992) In: CATANI, Denice Bárbara, BASTOS, Maria Helena Câmara. Educação em Revista: a imprensa periódica e a história da educação. São Paulo: Escrituras, 1997, p. 47-76.

CATANI, Denice Bárbara; SOUSA, Cynthia Pereira de (org.). Imprensa periódica educacional paulista (1890-1996). São Paulo: Plêiade, 1999.

CERTEAU, Michel de. A invenção do cotidiano: 1 - artes de fazer. Petrópolis: Vozes, 2011.

CHARTIER, Roger. A história cultural: entre práticas e representações. Lisboa: Difel, 1990.

CHARTIER, Roger. A história entre narrativa e conhecimento. In: CHARTIER, Roger. À beira da falésia: a história entre certezas e inquietudes. Porto Alegre: Ufrgs, 2002, p. 81100.

DESAULNIERS, Julieta B. Ramos. A formação via impresso. In: CATANI, Denice Bárbara; BASTOS, Maria Helena Câmara. Educação em revista: a imprensa periódica e a história da educação. São Paulo: Escrituras, 1997, p. 127-154.

FARIA FILHO, Luciano; GONÇALVES, Irlen Antonio; VIDAL, Diana; PAULILO, André Luiz. A cultura escolar como categoria de analise e como campo de investigação na historia da educação brasileira. Educação e Pesquisa, São Paulo, v. 30, n. 1, 2004, p. 139-159.

JULIA, Dominique. A cultura escolar como objeto histórico. Revista Brasileira de Historia da Educação, Campinas: SBHE, n. 1, 2001, p. 9-44.

LIMA, Licinio. A escola como organização educativa. São Paulo: Cortez, 2001.

LOURENÇO FILHO, Manuel Bergström. A formação de professores: da Escola Normal à Escola de Educação. Brasília: Inep, 2001. 
NERY, Ana Clara Bortoleto; SERRA, Áurea Esteves. A política de formação de diretores e de professores em São Paulo na Primeira República. CONGRESSO IBERO AMERICANO DE POLÍTICA E ADMINISTRAÇÃO DA EDUCAÇÃO, 3, 2012, Zaragoza. Anais ... Zaragosa: Universidad de Zaragoza; Forum Europeu de Administración de La Educación, 2012.

NOVOA, António. A imprensa de educação e ensino. In: CATANI, Denice Bárbara, BASTOS, Maria Helena Câmara. Educação em Revista: a imprensa periódica e a história da educação. São Paulo: Escrituras, 1997, p. 11-32.

PINEDA, Silvana Schuler. Hyloea: as representações do feminino na revista dos alunos do Colégio Militar de Porto Alegre (1922-1938). CONGRESSO IBEROAMERICANO DE HISTORIA DA EDUCAÇÃO LATINOAMERICANA, 8, 2007, Buenos Aires. Anais ... Buenos Aires: Sociedad Argentina de Historia de La Educación, UBA, 2007.

PINEDA, Silvana Schuler. Hyloea: o feminino na Revista dos alunos do Colégio Militar de Porto Alegre (1922-1938). Porto Alegre: Ufrgs, 2003. 180f. Dissertação (mestrado em Educação). Universidade Federal do Rio Grande do Sul, Programa de Pós-Graduação em Educação.

PRADO, Adonia Antunes. Ruralismo pedagógico no Brasil no Estado Novo. Estudos, sociedade e agricultura, Rio de Janeiro: UFRRJ, 1995, p. 5-27.

SCHNEIDER, Juliete. A democratização do acesso ao ensino secundário pela expansão do ciclo ginasial em Santa Catarina (1946-1969). Florianópolis: UFSC, 2008. $171 f$. Dissertação (mestrado em Educação). Universidade Federal de Santa Catarina, Programa de Pós-Graduação em Educação.

SERRA, Áurea Esteves. O Grêmio Normalista 2 de agosto e seu impresso: O Estímulo. CONGRESSO BRASILEIRO DE HISTORIA DA EDUCAÇÃO, 6, 2011, Vitória. Anais ... Vitória: SBHE/UFES, 2011.

SERRA, Áurea Esteves. Associação dos alunos da Escola Normal Secundária da Capital: o periódico O Estímulo. CONGRESSO DE LEITURA DO BRASIL, 17, 2009, Campinas. Anais ... Campinas: Unicamp, 2009.

SILVA, Emerson Correia da. A configuração do habitus professoral para o aluno-mestre: a Escola Normal Secundária de São Carlos (1911-1923). Marilia: Unesp, 2009. $125 f$. Dissertação (mestrado em Educação). Universidade Estadual Paulista, Programa de PósGraduação em Educação.

SOUZA, Andréia Maria Wollinger de; AGUIAR, Letícia Carneiro. A formação dos profissionais da educação em Santa Catarina: o Curso Normal em debate. SIMPÓSIO BRASILEIRO DE POLÍTICA E ADMINISTRAÇÃO DA EDUCAÇÃO, 24, 2009, Vitória. Anais ... Vitória: Anpae/Ufes, 2009.

SOUSA, Cynthia Pereira de. A educação pelas leituras: registros de uma revista escolar (1930-1960). In: CATANI, Denice Bárbara; BASTOS, Maria Helena Câmara. Educação em revista: a imprensa periódica e a história da educação. São Paulo: Escrituras, 1997, p. 93-110.

SOUZA, José Boaventura de. Escola Normal de Juazeiro: uma experiência pioneira. Juazeiro do Norte: Ipesc, 1994.

VIÑAO, Antonio. Sistemas educativos, culturas escolares y reformas. Madrid: Morata, 2002. 
WERLE, Flávia Obino Corrêa. Escola normal rural no Rio Grande do Sul: contexto e funcionamento. In: Flávia Obino Corrêa Werle (org.). Educação rural em perspectiva internacional. ljuí: Unijuí, 2007, p. 155-196.

WERLE, Flávia Obino Corrêa; BRITO, Lenir Marina; NIENOV, Gisele. Escola normal rural e seu impresso estudantil. Educação em Revista, Belo Horizonte: UFMG, v. 1, 2007, p. 81-105.

WERLE, Flavia Obino Corrêa, METZLER, Ana Maria Carvalho; BRITO, Lenir Marina Trindade de Sá; COLAO, Cinthia Merlo. Um espaço esquecido de formação do professor: a escola normal rural. In: CORSETTI, Berenice; TAMBARA, Elomar. Instituições de professores no Rio Grande do Sul. Pelotas: UFPel, 2007, p. 63-102.

WERLE, Flávia Obino Corrêa; BRITO, Lenir Marina Trindade de Sá. O professor e a escola para a zona rural: concepções e desdobramentos em uma escola normal rural. Contexto e Educação, ljuí: Unijuí, v. 21, n. 75, 2006, p. 109-129.

WERLE, Flavia Obino Corrêa. Formação de professores para o ensino de primeiras letras na zona rural. Brasil, final do século 19. História da Educação, Porto Alegre: Asphe, v. 12, n. 24, 2008, p. 121-153.

WERLE, Flávia Obino Corrêa. Modernizando os cursos de formação de professores: disciplinarização da Pedagogia e deslocamento da prática. In: FERREIRA, Naura Syria Carapeto (org.). Formação continuada e gestão da educação. São Paulo: Cortez, 2003, p. 251-304.

WERLE, Flávia Obino Corrêa. Práticas escolares em escolas normais rurais do Rio Grande do Sul (1940-1970). In: GONÇALVES NETO, Wenceslau; MIGUEL, Maria Elisabeth Blanck; FERREIRA NETO, Amarilio (org.). Práticas escolares e processos educativos: currículo, disciplinas e instituições escolares (séculos 19 e 20). Vitória: Edufes, 2011, p. 255-278.

FLÁVIA OBINO CORRÊA WERLE é professora na Universidade do Vale do Rio dos Sinos.

Endereço: Avenida Unisinos, 950 - 93022-000 - São Leopoldo - RS - Brasil.

E-mail: flaviaw@unisinos.br.

Recebido em 19 de agosto de 2012.

Aceito em 2 de fevereiro de 2012. 